\title{
$X X$. Some concluding remarks on the theory of vanishing franctions
}

\section{J.R. Young Esq.}

To cite this article: J.R. Young Esq. (1836) XX. Some concluding remarks on the theory of vanishing franctions, Philosophical Magazine Series 3, 9:52, 92-96, DOI: 10.1080/14786443608648954

To link to this article: http://dx.doi.org/10.1080/14786443608648954

册 Published online: 01 Jun 2009.

Submit your article to this journal $[\pi$

Џ Article views: 2

Q View related articles $₫$ 
XX. Some concluding Remarks on the Theory of Vanishing Fractions. By J. R. Young, Esq., Professor of Mathematics, Belfast College.*

V R. WOOLHOUSE's letter in the preceding Number of this Magazine (p. 18) renders it befitting that I should offer a few additional observations; although 1 had hoped that the many examples 1 had given of the entire fallacy of the principles in dispute, would have rendered any further recurrence to the subject on my part quite unnecessary. As far indeed as that letter can be regarded as a "reply" to my ar. guments, I see nothing, I must confess, to justify me in prolonging the discussion. It clearly, however, establishes the fact that Mr. Woolhouse has all along laboured under a mistake as to what the processes of mathematicians in the doctrine of vanishing fractions really are, for he asserts these processes to involve the absurdity of "multiplying and dividing by zero", and fancies that, by defending "the usual methods," I attempt to justify such operations.

Mr. Woolhouse says that his "especial object in writing the Essay was to show the impropriety of multiplying and dividing by zero," and he urges my attention to the logical inaccuracy of such processes. Now it appears to me that Mr. Woolhouse would have been as profitably employed in writing to show the impropriety of making two and two equal to five; for the fallacy which he denounces is never committed; and if, as indeed his letter shows, he has imagined this fallacy in the reasonings of Lacroix and Bourdon, to which I have already referred him, he has been the subject of a rather singular delusion. With this erroneous impression on his mind, however, it is not difficult to conceive how he has been led to make so many remarkable statements in reference to analytical processes and analytical results: he has been combating a doctrine which exists only in his own imagination; and all the "palpable inconsistencies" which he has discovered belong, not to the true theory which mathematicians have laid down, but to the fanciful system which $\mathrm{Mr}$. Woolhouse has set up, unwittingly, in its stead.

Mr. Woolhouse has evidently adopted the old and exploded notion--indulged, I believe, by no other person living - that the elimination of the vanishing factor, - as, for instance, $x-a$, in such a case as $\frac{x^{2}-a^{2}}{x-a}$, is a mere artificial contrivance, to bring out, in the hypothesis of $x=a$, one only of the innumer-

* Communicated by the Author. 
able values which the expression is competent to give, seeing that it then assumes the indeterminate form $\frac{a^{2}-a^{2}}{a-a}$. He has allogether overlooked the fact that the questions, What is the value of $\frac{x^{3}-a^{3}}{x-a}$ when $x=a$ ? and, What is the value of $\frac{a^{2}-a^{2}}{a-a}$ ? (questions which have certainly been confounded before,) are perfectly distinct. The value of $\frac{x^{2}-a^{2}}{x-a}$ when $x=a$ is not $\frac{a^{2}-a^{2}}{a-a}$, as $\mathrm{Mr}$. Woolhouse supposes; this is merely the symbolical form which $\frac{x^{2}-a^{2}}{x-a}$ assumes in that case. The value of $\frac{x^{2}-a^{2}}{x-a}$ is $x+a$; and this value when $x=a$ is $2 a$. The expression $\frac{x^{2}-a^{9}}{x-a}$ implies an operation to be performed, viz. division, and the value is the result of that operation. When the form $\frac{a^{2}-a^{2}}{a-a}$ is isolated, or detached from its interpretation, it is of course indeterminate ; for the operation indicated requires that we determine such a quantity $P$, that when it is submitted to the reverse operation, $(a-a) \mathrm{P}$, the result may be $a^{2}-a^{2}$; and it is easily seen that an infinite variety of suitable values for $\mathrm{P}$ exist; for it may be generally expressed by

$$
\mathrm{P}=(a+a) \pm p \text {. }
$$

But the result of the operation $\frac{x^{2}-a^{2}}{x-a}$ is definite, and distinctly points out which of the above infinite variety is comprehended among the values of $\frac{x^{2}-a^{2}}{x-a}$ in the ultimate state of the hypothesis, to the exclusion of all others.

Mr. Woolhouse fancies that when a vanishing factor, $x-a$, is introduced into an algebraic process an indeterminateness is introduced at the same time. This is contrary to fact, and to the doctrine of all writers on the subject. The introduction of a foreign factor, whether by elimination or otherwise, can nerer affect the analytical limitations which existed before its entrance; and it is the well-known and universal practice of analysis to reject these foreign factors at the close of the process, although they are not always discoverable without an 
"appeal to the original analytical conditions." In the case, however, of what has been called a vanishing factor, the expulsion is always easily effected by the usual method of vanishing fractions, and $\mathrm{Mr}$. Woolhouse will find upon examining any modern author that nothing more is effected.

Mr. Woolhouse appears to fall into great inaccuracy of reasoning at page 22 , when he infers that the introduction of the factor $x-a$ into the equation

$$
0=(x-a)^{\alpha-\beta} \theta . x-y \Phi x, \ldots . . . . \ldots . . .
$$

must introduce new values for $y$; or when he supposes that the result of this introduction, viz.

$$
0=(x-a)\left\{(x-a)^{\alpha-\beta} \theta x-y \Phi x\right\}, \ldots \ldots \ldots\left(p_{.}\right)
$$

is equivalent to the two independent equations

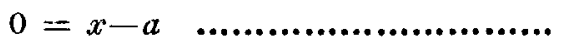

$$
\begin{aligned}
& 0=(x-\alpha)^{\alpha-\beta} \theta x-y \$ x
\end{aligned}
$$

If Mr. Woolhouse regard this as sound logic, the logic of Lacroix must seem to him " palpably inconsistent" indeed. I beg to suggest to $\mathrm{Mr}$. Woolhouse that his equation $(r$.) does not exist independently of, but only simultaneously with, the equation (s.); and he will not be able to point out any writer who argues otherwise. $\mathrm{He}$ is also wrong in affirming that the equation $(p$.$) , due regard being paid to the circum-$ stance of a foreign factor entering it, becomes indeterminate for $x=a$. That equation, as to number of admissible values, is identical with $(s$.$) . If this be satisfied for x=a$, then $x=a$ will be an admissible solution of $(p$.$) , but not else,$ seeing that $(p$.) resolves itself, when $x=a$, into the two simultaneous equations $(r$.$) and \left(s_{0}\right)$; and it is distinctly in reference to this circumstance that the solutions of $(p$.$) are to$ be viewed.

Such is, in substance, the doctrine of all modern analysts, but it is very different from that which Mr. Woolhouse has gratuitously condemned. I regret that he did not examine, with more attention, the process of Lacroix, in solving the problem of Clairaut, to which I referred him in my former letter. I think if he had done this, instead of passing over in silence so decided an argument against his own "principles" as that process furnishes, he surely would have spared the truisms with which his " Reply" abounds.

It is no doubt possible that $\mathrm{Mr}$. Woolhouse may have met with some obscure work in which his zero processes may occur. I certainly have never seen any such work; and if one 
exist it must be perfectly unique; and I trust that Mr. Woolhouse will make it known to the public, in order that connoisseurs may possess themselves of so singular a specimen of scientific absurdity.

From what $I$ have now said it will be seen that I deny, in toto, the justness of Mr. Woolhouse's charge of bad logic in the common processes of the doctrine of vanishing fractions; and I have moreover very briefly shown how those processes ought to be interpreted. It is only upon this assumed bad logic that $\mathrm{Mr}$. Woolhouse rests the stability of his remarkable "principles"; if then the logic is shown to be sound, but that Mr. Woolhouse has, unconsciously, misinterpreted the steps, what becomes of these said "principles"?

$I$ shall now take my leave of this subject; I have carefully examined my former letters, and do not find a single remark which I wish to recall, nor a single mathematical statement at variance with received and well-established principles. The only alteration I would wish to make is, that the word "may" be substituted for "will" immediately after equation (2.) at page 517 of last volume; the "will " occurring for "may" justifies Mr. Woolhouse's foot-note at page 24.

Ample as are the materials which Mr. Woolhouse's last letter supplies for comment and objection, I shall in conclusion merely notice two points, more immediately concerning myself. At page 21, Mr. Woolhouse says that I "deny the competency of the results of the ellipse question to furnish the requisite values, and at the same time agree to receive them from the original analytical conditions." Mr. Woolhouse is again at fault; let him read what I really do deny, instead of attributing to me his own imaginings. I have said at page 298 (last volume) that " the fact of the problem admitting multiple solutions is information which the analytical result is incompetent to supply ;" this is very different from asserting that these multiple solutions, if they exist, could not be furnished by the result; the question is-do they exist or not? and on this question the result supplies no information. Again, Mr. Woolhouse appears to have views different from other people on the subject of singular solutions, or else he uses technical terms in reference to this topic, in an unauthorized sense. It is sufficient for me here, without inquiring into his peculiar notions, to show that my remark, in reference to this subject, is in strict accordance with the received language of analysis. I have said that "singular solutions, though not comprised in the resulting integrals which furnish the general solutions to certain differential equations, have nevertheless the property of satisfying the proposed conditions." Lagrange 


\section{$96 \mathrm{Mr}$. J. Nixon's Heights of Whernside, Great Whernside,}

expresses himself as follows: "La théorie des équations dérivées, porte naturellement à conclure que toute valeur qui peut satisfaire à une équation dérivée donnée doit être renfermée dans son équation primitive, pourvu que celle-ci ait toute la généralité dont elle est susceptible, par les constantes arbitraires qui doivent y entrer. Il y a néanmoins des equations dérivées auxquelles satisfont des valeurs que j'appelle singulières, parce qu'elles ne sont pas comprises dans leurs équations primitives *" Ayain: "On doit conclure de là que, pour que $x$ soit une valeur singulière non comprise dans la valeur générale, il faut," \&c.†

I here terminate these observations; nor shall I again trespass on the pages of the Philosophical Magazine, by any further remarks upon a subject which has now been so fully set before its readers.

July 6, 1836.

XXI. Heights of Whernside, Great Whernside, Rumbles Moor, Pendle Hill, and Boulsworth. By JoHn Nixon, Esq. $\neq$

TTHE following trigonometrical differences of level, measured at numerous stations for the determination of the above altitudes, having been calculated, under a range of distances of from four to thirty miles, with the constant refraction of the formula given in iny last (vol. viii. p. 480), are submitted as a severe test of its claims to general accuracy. The details of some of the measurements have been already given, and those of the remainder will appear in my surveys of Wharfdale, Ribblesdale, \&c.

For every station each day's observation of the difference of level between the standard hill and the other (calculated in the manner described in pages 437-8 of vol. vi.) is arranged in a separate line.

\section{Trigonometrical Differences of Level.}

\begin{tabular}{|c|c|c|c|c|c|c|c|c|}
\hline \multicolumn{4}{|c|}{ Whernside above Ingleborough. } & \multirow{2}{*}{\multicolumn{2}{|c|}{ At Ingleborough }} & \multicolumn{3}{|c|}{ Feet. } \\
\hline & & & Feet. & & & 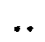 & . & $41 \cdot \%$ \\
\hline At Great Whernside & .. & $\cdots$ & $45 \cdot 0$ & & & ... & . & $38 \cdot 8$ \\
\hline Settronside§.. & . & $\ldots$ & $40.5(a)$ & & .. & $\cdots$ & .. & \\
\hline Hag & $\ddot{\cdots}$ & $\ddot{.}$ & $\begin{array}{l}41 \% \\
41 \cdot 8\end{array}$ & Penygent & $\therefore$ & $\ddot{.}$ & $\because$ & 40 \\
\hline ... & .. & .. & $40 \cdot 6$ & & .. & . & .. & \\
\hline
\end{tabular}

* Calcul des Fonctions, p. 178.

† Ibid., p. 234 .

f Communicated by the Author.

$\$$ The mark $(a)$ denotes that as there was no accompanying ubservation of the standard hill, its average difference of level was used in the calculation. 